\title{
Preparation of Autoclaved Foamed Concrete Block from Fly Ash and Carbide Slag
}

\author{
Xing Tan ${ }^{1}$, Fuqiang $\operatorname{Han}^{1}$, and Fengqing Zhao ${ }^{1,2^{*}}$ \\ ${ }^{1}$ Hebei University of Science \& Technology, Shijiazhuang 050018, PR China \\ ${ }^{2}$ Hebei Engineering Research Center of Solid Wastes Utilization
}

\begin{abstract}
To achieve the comprehensive utilization of solid waste and reduce costs, fly ash, carbide slag, and low-clinker cement were used to produce lightweight foamed concrete block. Granulated blast-furnace slag (GBFS) was used as composition correction material in the block. The effects of curing temperature and dosage of low-clinker cement on the performance of foamed concrete block were investigated. The optimal material proportioning is obtained: fly ash $58.5 \%$, carbide slag $20 \%$, GBFS $10 \%$, gypsum $1.5 \%$ and low-clinker cement $10 \%$. The proper curing regime is "temperature rising $4 \mathrm{~h}-180^{\circ} \mathrm{C}$ constant temperature $4 \mathrm{~h}$-natural cooling". The results indicate that the compressive strength of the block reaches $3.55 \mathrm{MPa}$ while the density is $616.9 \mathrm{~kg} / \mathrm{m}^{3}$. The performance of the product meets JC/T 1062-2007 (China professional standard of foamed concrete block).
\end{abstract}

\section{Introduction}

Wall materials innovation and energy saving in building are important parts in implementing sustainable development strategy in housing industry. Therefore, the development and application of energy-saving and insulated building materials have received extensive attention these years. With excellent properties of thermal insulation, acoustic insulation and light in weight, foamed concrete block has been one of the most promising materials these years ${ }^{[1]}$. Currently foamed concrete blocks on the market are mainly cement-based foamed concrete blocks ${ }^{[2-3]}$, with high cost and large consumption of cement.

Fly ash is a solid waste produced from coal-fired power plants. The annual emission of fly ash in China is more than 200 million tons, but the utilization ratio is relatively low, which will seriously pollute the environment if not treated properly ${ }^{[4]}$. An important application of fly ash is to produce autoclaved aerated concrete block, which is similar with foamed concrete block in performance, with lime in the present of aluminum powder ${ }^{[5-7]}$. In order to reduce the consumption of lime and production cost, carbide slag (a kind of solid waste, rich in calcium hydroxide) may be used to substitute for lime ${ }^{[8-9]}$. However, it has negative effect on the aeration of the slurry and the initial strength of the aerated block is

* Corresponding author: zhaofq3366@126.com 
low. Therefore the temperature in the slurry aerated block is the key problem in the use of carbide slag instead of lime.

For this reason, the fly ash slurry is mixed with foam directly, and a pre-curing process is used to increase the initial strength of the foamed concrete before cutting. GBFS and low-clinker cementitious material are used instead of OPC, to obtain high-performance lightweight block, achieving the synergistic effect among the materials and making the best use of various solid wastes.

\section{Materials and methods}

\subsection{Materials}

The fly ash used in the test is from Pingshan Power Plant; carbide slag is available for sale; cement used is the Ordinary Portland cement, strength grade 42.5; desulphurized gypsum is the industrial by-product of wet process desulfurization from coal power plant; GBFS is provided by a company in Tangshan, with a specific surface area of $408 \mathrm{~kg} / \mathrm{m}^{2}$; low-clinker cement with the basic material ratio: GBFS $66.4 \%$, steel slag $16.6 \%$, cement $8 \%$, gypsum $8 \%$, sodium sulfate $1 \%$; foaming agent, LG-2258 is bought from the market. The chemical compositions of the main raw materials are shown in Table 1.

Table 1. Chemical composition of main raw materials, $\mathrm{wt} \%$.

\begin{tabular}{|c|c|c|c|c|c|c|}
\hline Raw material & $\mathrm{SiO}_{2}$ & $\mathrm{MgO}$ & $\mathrm{CaO}$ & $\mathrm{Fe}_{2} \mathrm{O}_{3}$ & $\mathrm{Al}_{2} \mathrm{O}_{3}$ & $\mathrm{SO}_{3}$ \\
\hline Fly ash & 54.41 & 0.63 & 7.01 & 5.84 & 27.15 & 0.81 \\
\hline Carbide slag & 3.34 & 0.21 & 93.79 & 0.31 & 1.72 & 0.50 \\
\hline GBFS & 39.05 & 8.47 & 30.98 & 13.65 & 2.53 & - \\
\hline
\end{tabular}

\subsection{Test methods}

\subsubsection{Preparation of foamed concrete block}

(1) Mix fly ash, carbide slag, GBFS, gypsum, cement, low-clinker cement in proportion; stir well to form slurry A.

(2) Dilute foaming agent with water in a mass ratio of 1:60 and put in a high-speed mixer, foaming.

(3) Mix the stirred slurry A with the foam to prepare uniform foam contained slurry B.

(4) Pour the slurry B into $70.7 \mathrm{~mm} \times 70.7 \mathrm{~mm} \times 70.7 \mathrm{~mm}$ mold, pre-curing at $50^{\circ} \mathrm{C}$ for 16 h.

(5) Cutting and stripping to form cubic samples.

(6) Put the test samples into the autoclave, curing at desired conditions. Current curing regime is "temperature rising $4 \mathrm{~h}-180^{\circ} \mathrm{C}$ constant temperature $4 \mathrm{~h}$-natural cooling".

\subsubsection{Product performance test}

The dry density and the compressive strength of foamed concrete of the samples are tested in accordance with JC/T 1062-2007. The samples were dried, weighed, and the average density of the samples is obtained with three samples. The mechanical strength values of the samples are tested on NYL-300A. 


\section{Results and discussion}

\subsection{Effect of GBFS content}

The foamed concrete blocks were prepared based on the basic formula: fly ash $68.5 \%$, carbide slag $20 \%$, cement $10 \%$, and $1.5 \%$ of gypsum. However, the initial strength values of the samples are too low. After autoclaving process, the final strength values of the samples are also very low. In order to increase the strength of the foamed concrete blocks, $10 \%, 15 \%, 20 \%, 25 \%$ and $30 \%$ of GBFS are added to the slurry respectively, the results are shown in Fig. 1.

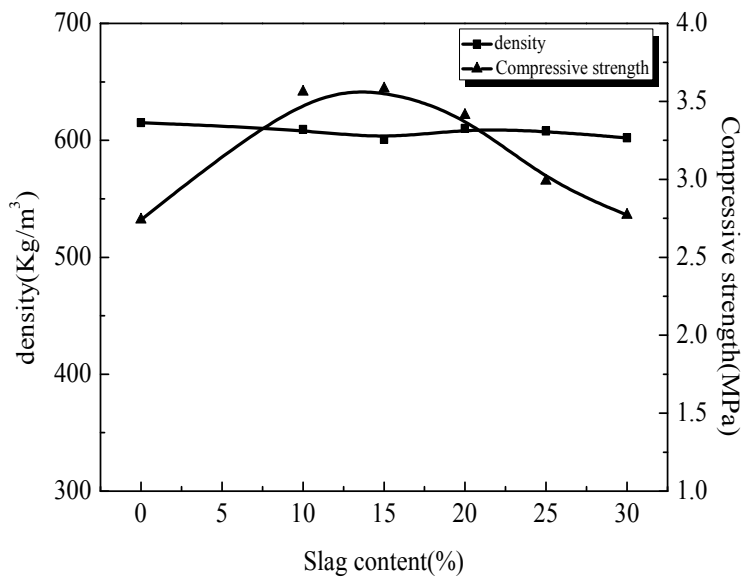

Fig. 1. Effect of GBFS content on performance of test block.

Fig.1 showed that the strength of the foamed concrete block is significantly increased after adding GBFS. With the increase of GBFS content, the compressive strength of the sample has a tendency to decrease. However, excessive GBFS content will bring more inert components, reducing the formation of the hydration products, and thus reduce the strength of the samples. Considering performance and cost, the optimal amount of GBFS is determined as $10 \%$.

\subsection{Effect of curing temperature}

With the suitable GBFS content $10 \%$, and the autoclaved curing regime "temperature rising 4h-constant temperature 4h-natural cooling", the performance of the test block is tested by changing the curing temperature. The results are shown in Fig. 2. 


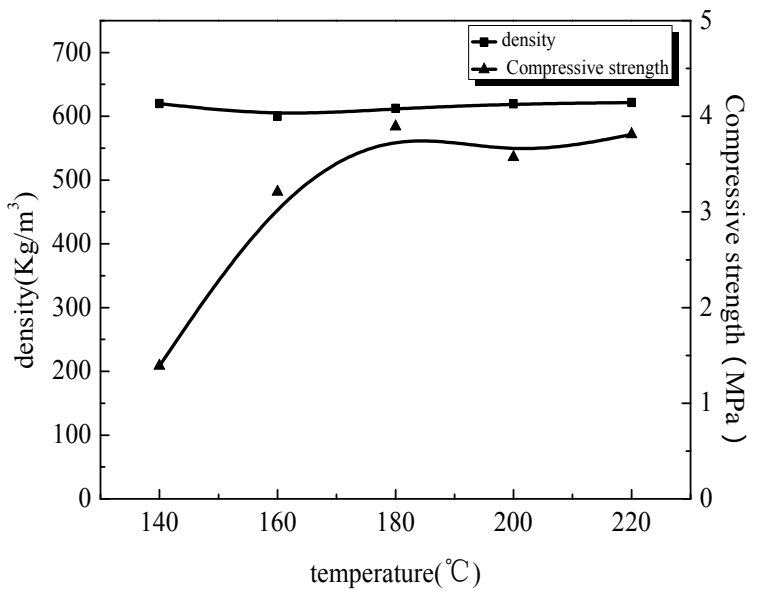

Fig. 2. Effect of curing temperature on performance of test block.

It shows that with the rise in curing temperature, the compressive strength of the block rises rapidly. When curing temperature is greater than $180^{\circ} \mathrm{C}$, the strength of the samples tends to increase smoothly. With the increase in temperature, more active substances in the block react to form hydration products like hydrated calcium silicate, hydrated calcium aluminate and tombomite etc., improving the strength of the block. In summary, the appropriate autoclaved curing temperature is $180^{\circ} \mathrm{C}$.

\subsection{Effect of constant temperature time}

With the mass ratio of fly ash, carbide slag, GBFS, cement and gypsum being 58.5: 20: 10: 10: 1.5 , autoclaved samples were prepared under the curing regime "temperature rising $4 \mathrm{~h}-180^{\circ} \mathrm{C}$ constant temperature-natural cooling". The performances of the samples were investigated by changing constant temperature time. The results are shown in Fig. 3.

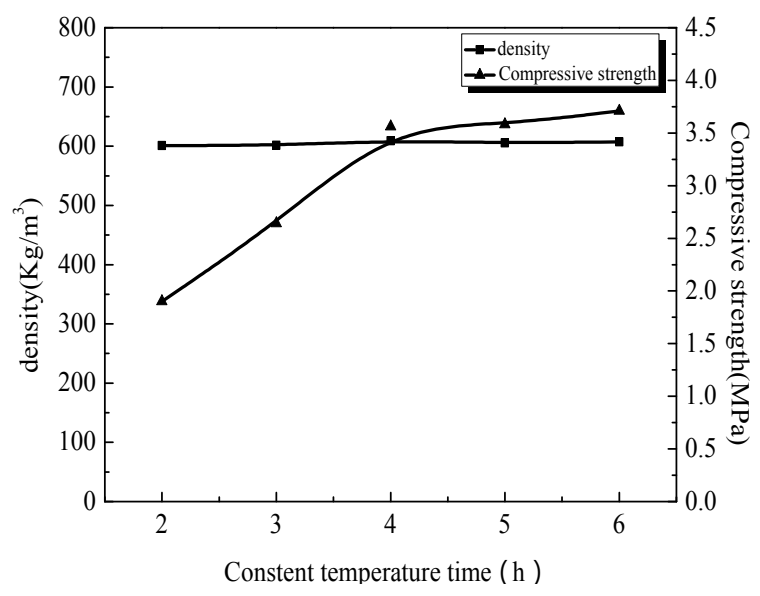

Fig. 3. Effect of constant temperature time on performance of test block.

It can be seen from Fig. 3 that with the extension of the constant temperature time, the compressive strength of the foamed concrete block gradually increases. While constant temperature time is less than $4 \mathrm{~h}$, the compressive strength of the sample increases rapidly 
with the time. When the time is above $4 \mathrm{~h}$, the strength value tends to increase smoothly. The appropriate autoclaved constant temperature time is $4 \mathrm{~h}$.

\subsection{Effect of cementitious materials}

In order to further reduce the cost, save energy and reduce $\mathrm{CO}_{2}$ emissions, low-clinker cement is used to substitute for OPC in $25 \%, 50 \%, 75 \%, 100 \%$, respectively. The curing regime is "temperature rising $4 \mathrm{~h}-180^{\circ} \mathrm{C}$ constant temperature 4h-natural cooling". The results are shown in Fig. 4.

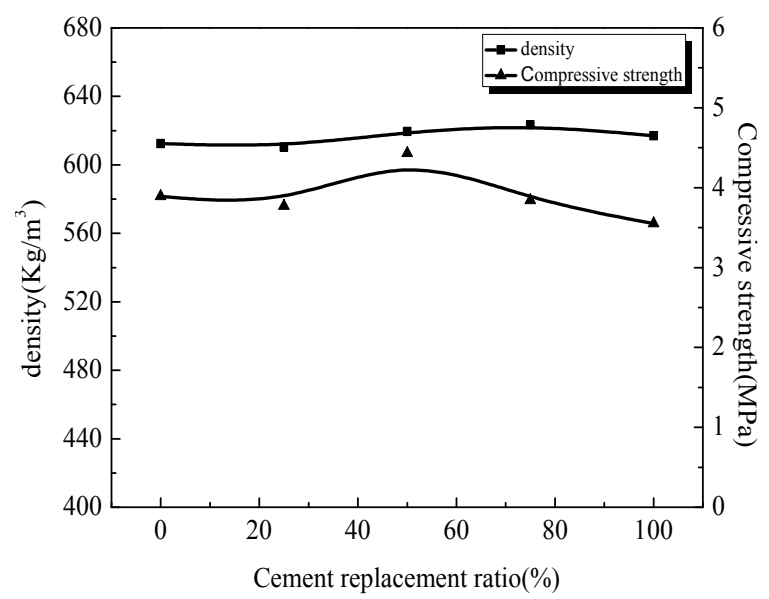

Fig. 4. Effect of low-clinker cement replacement on performance of test block.

As can be seen from Fig.4, with the increase in low-clinker cement replacement rate, the compressive strength of foamed concrete block increases first and then decreases, and all are greater than $3.5 \mathrm{MPa}$. When the replacement rate is $50 \%$, the strength reaches the peak. In order to reduce the cost, the optimal replacement ratio should be $100 \%$, i.e. low-clinker cement can be used to substitute for OPC totally in the process.

\section{Conclusions}

(1) Using fly ash, carbide slag and low-clinker cement instead of cement, can produce foamed concrete with desired mechanical strength and density. This approach solved the problem of poor aeration when carbide slag is used to substitute for lime in autoclaved aerated block production, and make the best use of various solid wastes. It has the advantage of low cost, energy saving and friendly to the environment.

(2) It is necessary to use GBFS to substitute for fly ash partly. Adding $10 \%$ of the GBFS to the slurry in the production of foamed concrete block increases the initial strength of the block and shortens the pre-curing time.

(3) When GBFS content is $10 \%$, curing regime is "temperature rising $4 \mathrm{~h}-180^{\circ} \mathrm{Cconstant}$ temperature 4h-natural cooling", the cement can be replaced with low-clinker cement totally. The compressive strength of the block reaches $3.55 \mathrm{MPa}$ while the density is $616.9 \mathrm{~kg} / \mathrm{m}^{3}$. The autoclaved foamed concrete conforms to JC/T 1062-2007.

(4) Appropriate autoclaved curing regime is beneficial to the hydration process. Excessive curing temperature and too long constant temperature time contribute little to the block. The optimal autoclaved curing regime is "temperature rising $4 \mathrm{~h}-180^{\circ} \mathrm{C}$ constant temperature 4h-natural cooling". 


\section{References}

1. WL Tian, QQ Xiong, FL Jiang. Performance Impact Factor Analysis of Fly Ash Foamed Concrete. J. Journal of Shijiazhuang Tiedao University (Natural Science), 26(1):46-49(2013)

2. PT Gao. Discussion of foam concrete block property. J. Tile, 2:43-51(2012)

3. CQ Wang, KF Tan, XX Xu. Research status on foam concrete in China. J. Concrete, 12:57-62(2013)

4. S Zhang, GZ Li, WH Zhang, CC Jiang. Research on lightweight insulating concrete block with the composite cement fly ash foamer. J. Tile, 6:40-42(2011)

5. FQ Zhao, J Zhao, HJ Liu. Autoclaved brick from low-silicon tailings. J. Construction \& Building Materials, 23(1):538-541(2009)

6. FQ Zhao, B Guo, HJ Liu, \& JQ Liu. Utilization of High Carbon Fly Ash and Coal Gangue in Blended Cement: A Case Study. International Conference on Bioinformatics and Biomedical Engineering (pp.1-4). IEEE.(2009)

7. PG Li, FQ Zhao. Autoclaved Brick from Steel Slag and Silicon Tailings. J. Advanced Materials Research, 878:194-198(2014)

8. PG Li, FQ Zhao. Hydration intensification of autoclaved brick with high volume steel slag and tailings. J. Iron \& Steel, 51(10):84-90(2016)

9. SM Zhi, XX Jing,Z Wang. Research of Steam Curing Aerated Concrete by Substituting Lime for Carbide Slag. J. Construction Technology, 43(24):105-107(2014) 